Kirsti Marie Jegstad, former PhD-student at Section for Learning and Teacher Education at the Norwegian University of Life Sciences. She currently works at OsloMet - Oslo Metropolitan University. Her research interests include chemistry education, science education and education for sustainable development.

Dr. Astrid T. Sinnes, associate professor at Section for Learning and Teacher Education at the Norwegian University of Life Sciences. Her research interests include education for sustainable development, gender equity in science education, and science education for development.

Dr. Sigrid Marie Gjøtterud, associate professor at Section for Learning and Teacher Education at the Norwegian University of Life Sciences. Her research interests include educational action research and education for sustainable development.

\title{
KIRSTI MARIE JEGSTAD
}

Department of Mathematical Sciences and Technology, Norwegian University of Life Sciences, Norway kimaje@oslomet.no

\section{ASTRID TONETTE SINNES}

Department of Mathematical Sciences and Technology, Norwegian University of Life Sciences, Norway astrid.sinnes@nmbu.no

\section{SIGRID MARIE GJØTTERUD}

Department of Mathematical Sciences and Technology, Norwegian University of Life Sciences, Norway sigrid.gjotterud@nmbu.no

\section{Science teacher education for sustainable development: from intensions to realisation}

\begin{abstract}
Teacher education programs have an especially important role in reorienting education to realise education for sustainable development (ESD). In this paper, we investigate how ESD can be realised in science teacher education and we present findings from a case study in a Norwegian teacher education institution that has the overall aim of educating teachers who can contribute to sustainable development. Data was collected through participant observation and interviews, and, together with instructional artefacts and student assignments, analysed based on a model for science ESD. The paper provides an example of how ESD can be realised through a strengths model where ESD is founded in the strengths among the teacher educators and existing teaching practices. The results indicate that an emphasis on experiential learning and sociocultural learning theory builds a thorough foundation for ESD. However, the teaching has to be explicit in order to reach all student teachers.
\end{abstract}




\section{INTRODUCTION}

The teachers of today are educating the future leaders and citizens of the world; they therefore play an important role in education for sustainable development (ESD) (Hopkins \& McKeown, 2002). However, several studies have found that teachers struggle to realise ESD in their teaching (Burmeister \& Eilks, 2013; Burmeister, Rauch, \& Eilks, 2012; Sinnes \& Jegstad, 2011). One of the challenges teachers face with respect to the realisation of ESD has been identified as the inclusion of even more content into an already overloaded curriculum. It has therefore been suggested that ESD be integrated as a perspective applied across the content in all existing subjects (Jegstad \& Sinnes, 2015; Rudsberg \& Öhman, 2010).

ESD has been on the political agenda in the past decades, especially through the United Nation's decade of ESD (UNESCO, 2005) and thereafter the Global Action Programme (UNESCO, 2016). The ability and capacity to realise ESD at school level depend on teachers' knowledge and beliefs about both the subject matter and pedagogy. Thus, teacher educators play an important role in facilitating the development of student teachers' professional understanding and practice within ESD (Corney \& Reid, 2007). The purpose of this study is to investigate how a teacher education institution with the overall aim of educating teachers who can contribute to sustainable development includes such practices in its science teacher education program. ESD as an overall aim of teacher education is rare in the research literature and the paper therefore provides insight into a previously little researched area.

The importance of teacher education programs in preparing their student teachers to realise ESD in the classroom has been acknowledged for several decades (Scott, 1996). Borg, Gericke, Höglund and Bergman (2012) investigated subject-bound differences among teachers in realising ESD and found that they were strongly influenced by their own subject tradition from their own higher education and teacher education programs. For science teachers, this meant that the teachers tended to be oriented towards the fact-based teaching tradition, where environmental issues are seen as knowledge problems which can be solved by carrying out more research and informing the public (Rudsberg \& Öhman, 2010). However, a content focus on the problems of today's society is not enough to achieve a sustainable future; one also needs a general education in societal participation (Burmeister \& Eilks, 2013; Wals, 2011). A teaching tradition in line with ESD principles would be more pluralistic and acknowledge different perspectives, views and values (Borg et al., 2012). These findings point to the specific challenges for science teachers with respect to the realisation of ESD, which in turn raises challenges for science teacher education programs.

The research question explored in this paper is how can ESD be realised in science teacher education? The research question is investigated by analysing the case of a teacher education program in Norway and will be answered based on two auxiliary research questions; how is ESD realised in an ESD-oriented science teacher education program and how do the student teachers in the teacher education program demonstrate their understanding of ESD?

An ESD model for planning and analysing science ESD (Jegstad \& Sinnes, 2015) was used in the analysis. This model will be presented in the next section, together with the theoretical perspectives that the paper builds on. The result section is guided by the auxiliary research questions, which will then be further called upon to answer the main research question. Both the actual realisation of ESD and how the realisation can be improved will be discussed.

\section{THEORETICAL PERSPECTIVES ON ESD IN SCIENCE TEACHING AND LEARNING}

ESD is about preparing the younger generation to become 'responsible citizens' (Burmeister et al., 2012, p. 59), i.e. citizens with respect for other human beings (both present and future generations) 
and for the planet and what it provides (e.g., resources, flora and fauna). This responsibility is connected to both action and decision-making (Summers, Childs, \& Corney, 2005), and raises challenges for teacher education programs. They have to help student teachers to realise ESD within a school system, where subject requirements are of central interest. New demands are placed on the selection of content, processes and the context, and student teachers need a clear rationale for the use of different teaching and learning strategies, as well as support in the actual ESD.

According to Hopkins and McKeown (2002), the most realistic way to realise ESD globally is through a 'strengths model', where the approaches towards ESD are adapted to the context and the strengths among the educational labour force:

Once the concept of sustainability is broadly understood and the need to reorient education is accepted, the way forward will be greatly enhanced by combining the contributions of traditional disciplines and the experience and creativity of current teachers and administrators. (Hopkins \& McKeown, 2002, p. 22)

Moreover, support for the actual realisation is also needed and we therefore published a theoretical model for planning and analysing science ESD (Jegstad \& Sinnes, 2015). The model acknowledges that the subject, with all its curricular demands, has a distinct role, but by focusing on education through science (Holbrook, 2005) - where the emphasis is on how general educational skills may be promoted through the subject of science -, the other elements of ESD can be realised. Figure 1 presents the model, which consists of five categories, illustrated through five ellipses. Within each category, there are sub-categories that specify the content of the ESD categories.

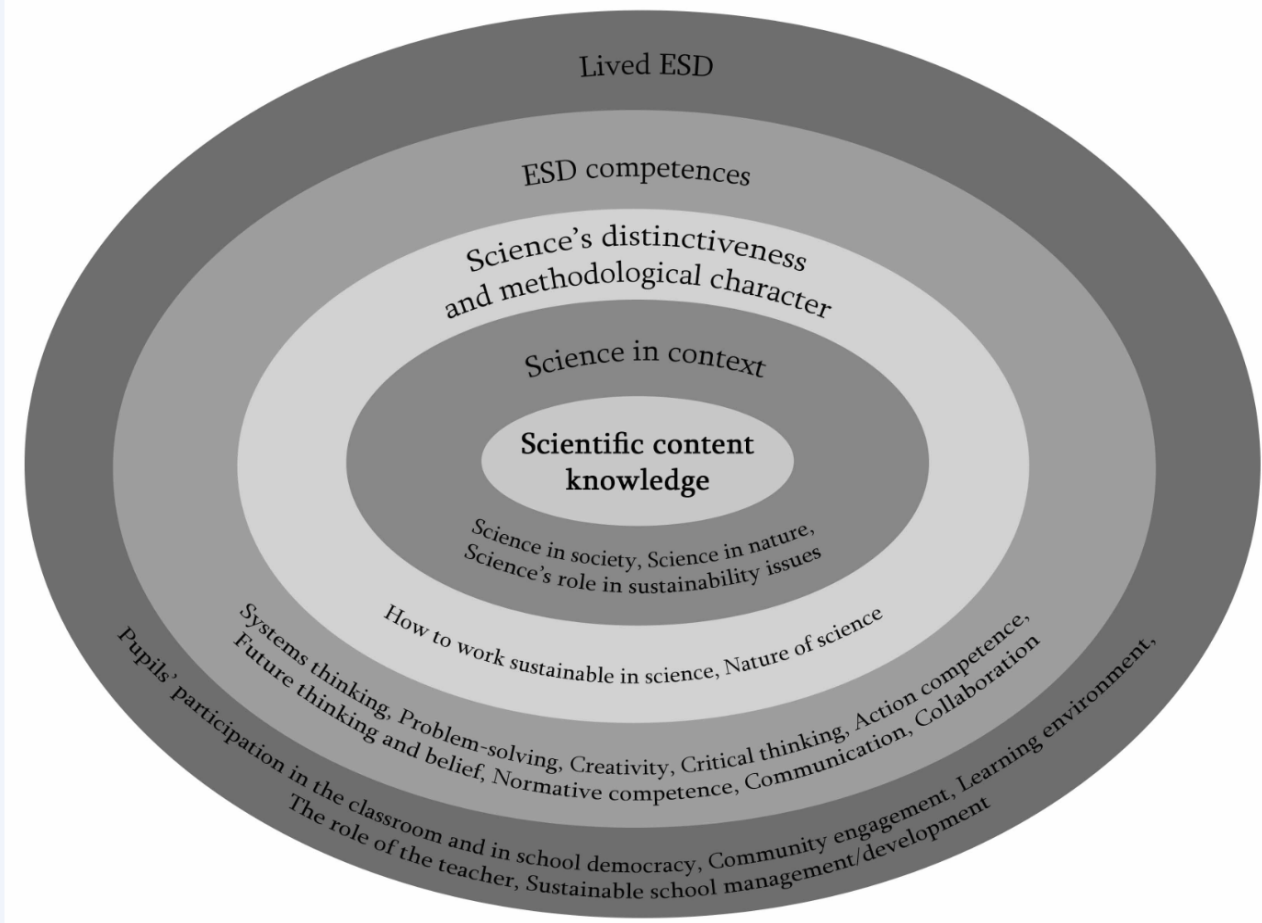

Figure 1. A model for planning and analysing science ESD (Jegstad \& Sinnes, 2015) 
The central ellipse, scientific content knowledge, covers content knowledge that is relevant for sustainability, including background knowledge (Jegstad \& Sinnes, 2015). However, regardless of the sustainability focus in the content knowledge being taught, the science class may be an arena for ESD simply by emphasising other ellipses of the model.

Situating the subject within a context is especially important in ESD, and this can be done for all topics. Dillon (2012) pointed to the mutual benefits of linking the content to a sustainability context, as pupils would become more interested in learning science in conjunction with a specific sustainability issue. Further, the third ellipse, the subject's distinctiveness and methodological character, is enhanced through emphases on the nature of science (NOS) and the sustainability practices within the specific scientific discipline, e.g. green chemistry (Karpudewan, Hj Ismail, \& Mohamed, 2011; Ware, 2001). NOS is connected to the influence of the scientists and how they make generalisations and theory based on scientific inquiry, which emphasises the importance of understanding scientific research methods. It also includes the tentative and uncertain nature of scientific knowledge (Lederman \& Lederman, 2012).

The ESD competencies listed in Figure 1 may be the foundation of all working methods regardless of the topic and context, and the emphasis is on the ESD competencies that may be promoted when participating in science-related activities (Jegstad \& Sinnes, 2015). The concept of ESD competencies has been emphasised by scholars in the field of ESD (de Haan, 2010; Jegstad \& Sinnes, 2015; Rauch \& Steiner, 2013; Voogt \& Roblin, 2012; Wiek, Withycombe, \& Redman, 2011) and includes the competencies of systems thinking, problem-solving, creativity, critical thinking, action competence, future thinking and belief, normative competence, communication and collaboration.

Finally, the placement of lived ESD in the outer ellipsis illustrates that principles from this category can be the foundation for everything that happens at school, both in the classes in particular and in the school in general. Hence, lived ESD can be considered a frame in which the other ESD categories lie, and it offers the pupils a friendly and safe learning environment. In sustainable schools, collaboration, flexibility and trust are important, diversity is valued and everyone is treated with respect (Sterling, 2009).

The ESD model was originally developed with secondary schools in mind, and four out of five ellipses do therefore focus on the pupils and what they need to know or be able to do. The focus in lived ESD is, on the other hand, divided between pupils (in community engagement), the teacher (in pupil participation, learning environment and the role of the teacher) and the school as organisation (in sustainable school management/development).

All categories had a distinct meaning within the secondary school context. This meaning was further developed within the context of the science teacher education program when the student teachers were prepared for ESD. Thus, even though the sub-categories were developed in advance, their meanings were expanded in the context based on the ESD construction in the teacher education program. We will return to this ESD construct in the discussion section of the paper.

\section{METHODOLOGY}

According to Corcoran, Walker, and Wals (2004), a case study is an appropriate research tool for studying sustainability in higher education due to the flexible and adaptive nature of the methodology. It is further applicable when explanatory questions, such as 'how' and 'why' questions, are posed (Yin, 2009). 
In the study, a one-year teacher education program for candidates with an academic or vocational educational background in science, mathematics and/or agriculture constituted the case. The teacher education program amounted to 6o ECTS credits (one-year full-time study) and the student teachers attending the science teacher education program already possessed a Bachelor's, Master's or doctoral degree in a scientific subject. The program was organised through twelve, week-long modules; six of these modules were in science education while the remaining six were in pedagogy. The student teachers also carried out twelve weeks of practical training in schools and four major mandatory assignments: two individual assignments in science education, one individual assignment in science education and pedagogy (combined) and one group assignment in pedagogy.

The research has been carried out in our own organisation. The first author has been in charge of the data collection and analysis. She was a student teacher in the teacher education program before ESD became the overall aim, and has throughout the research period contributed in some teaching sessions and guided some student teachers. Both the second- and third authors have been working in the teacher education program for more than a decade and have contributed strongly in the development of the ESD expression.

\section{Data collection}

The case was followed over consecutive years (2010, 2011 and 2012) and the paper builds mainly from data from the academic year 2011/2012. Data has been collected widely in order to gain a deep understanding of the realisation of ESD in the teacher education program. We carried out participant observations in both meetings which involved planning the teaching sessions and in the actual teaching sessions, and interviews. The data corpus also included instructional artefacts such as handouts, presentations and other documents available to the student teachers, documents related to meetings in the teacher education institution and various assignments.

In order to analyse how ESD was realised in the teacher education program, we analysed relevant teaching sessions in the six science education modules, the six pedagogy modules and the general perspective of the teacher education program. The general perspective covered activities and aspects that were not visualised in the analysis of the specific modules. This included logs (a tool that is widely used in the teacher education program to increase the ability of the student teachers to reflect); student democracy; the learning environment and social aspects of the teacher education program; and topics that were outside the teaching modules such as practical training. Hence, in the general perspective, we analysed aspects of the teacher education program that was present throughout the year, across the specific modules.

The relevant science education sessions were chosen based on our knowledge from the observations of the sessions and participation in meetings planning these sessions. When doubt occurred as to whether a session was relevant or not, the session was nevertheless included in the analysis. We also included the pedagogy modules in the analysis, since we found the ESD expression in the science teacher education program to be dependent on both the science education and pedagogy modules. The data used in the analysis is listed in Table 1. 
Table 1: List of data material used to analyse the realisation of ESD in the teacher education program

\begin{tabular}{|l|}
\hline Data \\
\hline Schedules of each of the 12 teaching modules with information letters describing the modules \\
\hline PowerPoints and memos handed out in the teaching sessions analysed \\
\hline $\begin{array}{l}\text { Sound recordings from semi-structured interviews with four teacher educators and from a focus } \\
\text { group conversation with four teacher educators about ESD in the pedagogy modules }\end{array}$ \\
\hline Participant observations of teaching sessions \\
\hline Participant observations and sound recordings from meetings planning the teaching sessions \\
\hline Reflection notes written by the first author \\
\hline Reports from meetings and documents handed in as participant preparation for meetings \\
\hline $\begin{array}{l}\text { Curricula for the teacher education program (national and local curriculum for the teacher educa- } \\
\text { tion program and the local curriculum for the practical training) }\end{array}$ \\
\hline $\begin{array}{l}\text { Report from the external evaluation of the teacher education programs and a self-report written } \\
\text { as preparation for the external evaluation (one study program at the university is evaluated each } \\
\text { year and in 2012, the teacher education program was the subject of evaluation) }\end{array}$ \\
\hline
\end{tabular}

To explore the student teachers' understanding of ESD, we analysed the data material listed in Table 2. Our main emphasis in this analysis was on the student teachers' assignments written during the spring of 2012 and it included both the science education assignment and the combined assignment in science education and pedagogy. ESD was not a given topic in any of the assignments, but the student teachers' assignments play a major role in the teacher education program and they aim to develop the student teachers as future teachers (Gjøtterud, 2011). We also found the assignments to be good indicators of what the student teachers' main interests in education were.

Table 2: List of data material used to analyse the student teachers' understanding of ESD

\begin{tabular}{|l|}
\hline Data \\
\hline Student evaluation schemes \\
\hline $\begin{array}{l}36 \text { science education assignments written towards the end of the teacher education program, } \\
\text { where the students chose an issue within science education to discuss and experiences from the } \\
\text { practical training were linked to educational theory }\end{array}$ \\
\hline $\begin{array}{l}19 \text { exam preparative assignments, where the science students reflected on their development as } \\
\text { teachers }\end{array}$ \\
\hline $\begin{array}{l}17 \text { exam preparative assignments, where the combined science and agriculture students and the } \\
\text { combined science and mathematics students reflected on their development as teachers }\end{array}$ \\
\hline
\end{tabular}

The teacher education program has both full-time and part-time student teachers. The part-time student teachers attend modules in science education in the first year and modules in pedagogy in the second. Hence, only the exam preparative assignments of the full-time student teachers were analysed and we analysed 19 assignments - compared to 36 science education assignments. 


\section{Data analysis}

All data was analysed according to the research questions using meaning categorisation (Kvale, 1996). The categories used were the 18 sub-categories of the ESD model (Jegstad \& Sinnes, 2015).

The six science education modules were analysed session by session. We analysed in total 30 sessions from the science education modules. In the analysis, we differentiated between the levels of inclusion of each sub-category that was identified: slight emphasis (the topic was not focused upon explicitly or the topic was in force through collateral learning) or emphasised. Thereafter, a holistic ESD expression of each module was summarised. In the summarised results, we operated with four levels of inclusion of the sub-categories: 1 = not covered; 2 = partly covered (1-2 sessions/module); $3=$ partly emphasised (2-4 sessions/module); and $4=$ recurrent emphasis (the majority of the sessions). There are no fixed boundaries in these levels, as both the length of each session and the level of inclusion (i.e. slight emphasis or emphasised) of the sub-categories in each session varied. Thus, the summarised ESD expression of each module was evaluated separately.

On the other hand, each pedagogy module was analysed as an entity, as most sessions within a module were within the same topic. These modules were therefore directly analysed with the use of the four levels. The same applied for the general perspective of the teacher education program. The results of the analysis are listed in a table, followed by a presentation of the ESD expression, including translated quotes from teacher educators responsible for the topic.

In the analysis of the assignments, the emphasis was on the inclusion of the categories from the ESD model. The student teachers did not necessarily discuss ESD as a concept in the assignment, but they had to explicitly describe and discuss elements from the model for it to count in the analysis: 21 out of 36 science education assignments and 18 out of 19 exam preparative assignments followed this criterion and only these assignments are included in the diagrams in the result section of the paper. In the diagrams, we have differentiated between the levels of inclusion of each sub-category that was identified: slight emphasis or emphasised. The result section also includes translated quotes that are found to be especially illustrative with respect to the student teachers' perception of the ESD categories. We have included quotes from both student teachers who showed a particularly well-developed understanding of ESD and from the more typical assignments. The names used in these excerpts are pseudonyms.

The strength of a case study lies in the variety of empirical material that can be used in the analysis (Yin, 2009) and in the possibility of triangulation. The data from this case study was triangulated in two steps: firstly, data from different sources of informants and documents were combined in order to corroborate the analysis of the sessions of the teacher education program. Secondly, data from the perspectives of the teacher education program, the teacher educators and the student teachers was triangulated in order to corroborate the analysis of the teacher education program as an entity. Triangulation has thus contributed to the validity of the research project (Flick, 2004) and thorough documentation of the research procedures has contributed to the reliability (Kirk \& Miller, 1986).

\section{RESULTS}

\section{How is ESD realised in the science teacher education program?}

The teacher educators articulated the overall aim after realising that ESD was a topic of common research interest. They followed up on the aim by investigating how their own practices and research interests could be used in order to realise ESD in the teacher education program. The realisation of ESD in the teacher education program found in the analyses is presented according to the ESD model and the four levels of inclusion in Table 3 below. Each teaching module is presented separately, while the final column illustrates the general perspective of the teacher education program that is not covered in the analysis of the specific modules. 
Table 3. Realisation of ESD in the teacher education program

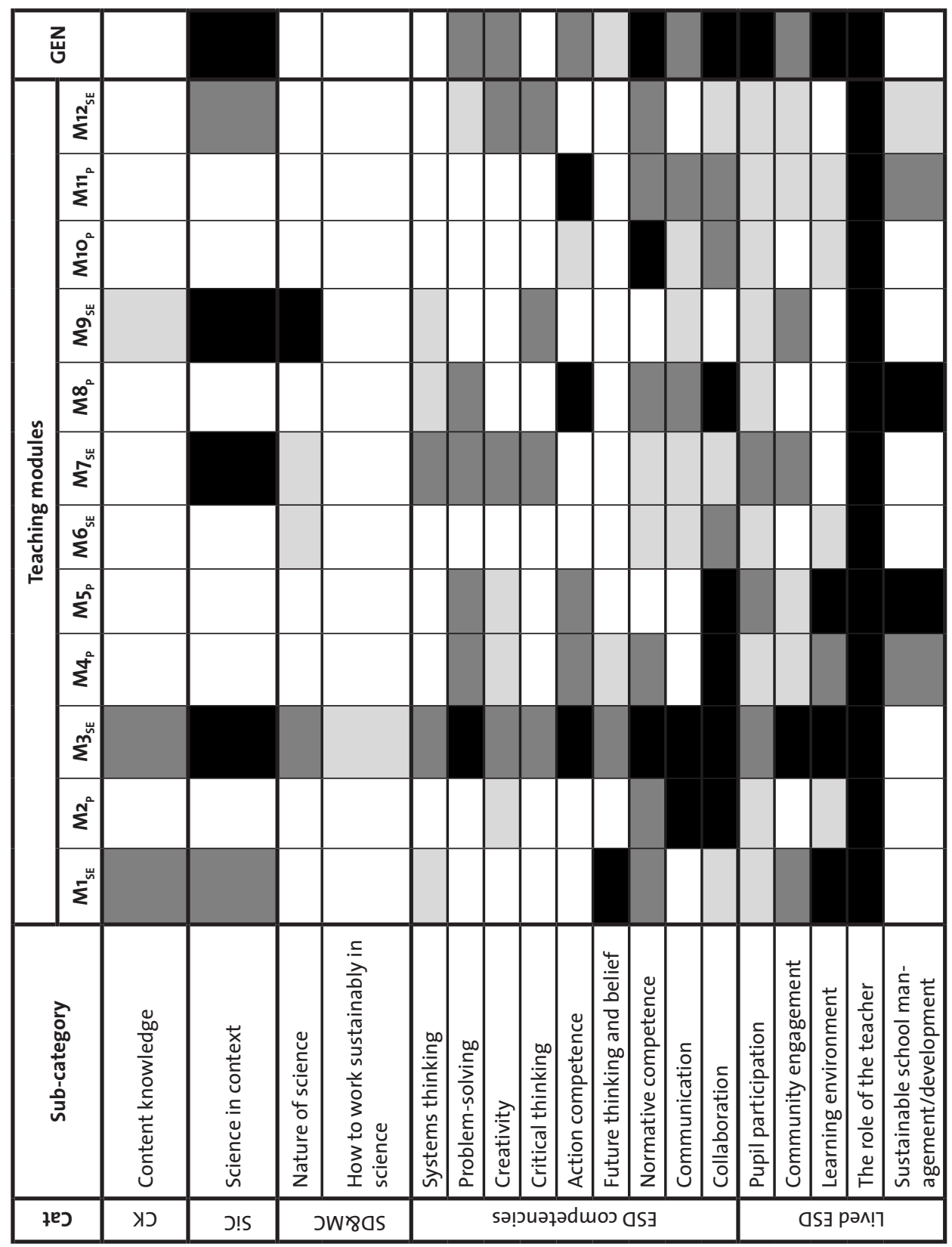

Colour codes: white $=$ not covered; light grey $=$ partly covered $(1-2$ sessions $/$ module); dark grey = partly emphasised (2-4 sessions/module); black = recurrent emphasis.

Each module is presented as a number and the subscript of the module heading illustrates whether the module was in science education (SE) or pedagogy (P). 
The analyses showed a recurrent emphasis on science in context and the ESD competencies of problem-solving, action competence, normative competence, communication and collaboration. Lived ESD was also largely emphasised, while NOS and the ESD competencies of systems thinking, creativity and critical thinking were addressed to some extent. In the following, we present the elements which contributed to the ESD expression in the teacher education program. The presentation will be related to the categories of the ESD model.

\section{Scientific content knowledge}

Due to the student teachers' scientific background (they all possessed a science degree), scientific content knowledge was not emphasised in the teacher education program. There were only a couple of lectures focusing on content knowledge, for example on the first day of the program, when attention was brought to ESD and the overall aim of the teacher education program through a lecture covering topics such as peak-oil, phosphorous deficiency, land protection, fuel sources and renewable energy sources. Otherwise, most content knowledge was introduced through collateral learning (Dewey, 1938), which is what one learns through and by doing other things, for example when the student teachers also learn about a specific topic when the purpose actually was to practice a specific teaching method.

\section{Science in context}

The ESD expression in the teacher education program was evident in the pedagogical principles and working methods of the teacher education program, i.e. sociocultural learning theory (Lave \& Wenger, 1991; Vygotsky, 1978) and experiential learning theory (Dewey, 1938). The pedagogical foundation of experiential learning led to a specific focus on context-based teaching and learning, and an emphasis on how the student teachers could make the societal relevance of science explicit in their teaching. For example, a residential field course was included at the beginning of the academic year in order to prepare the student teachers for outdoor classes.

Founded in experiential learning, self-regulated learning (Gjøtterud, 2011) and learner-active teaching approaches, such as phenomenon-based teaching and inquiry learning, were also emphasised in the teacher education programme. Phenomenon-based teaching (Dahlin, Östergaard, \& Hugo, 2009) is an inductive teaching approach, where theory is introduced to the learners after they have been exposed to a phenomenon (something perceptible). An example of how this was included in a teaching session was described by a teacher educator in an interview:

In a teaching session, a piece of charcoal was placed on one side of a long table and a green leaf was placed on the opposite side. This illustrated the story of the carbon cycle. The student teachers built the bridge together with the teacher educator - from the charcoal to the green leaf. I could not imagine a larger story.

When asked about how phenomenon-based teaching contributes to ESD, the same teacher educator pointed to the importance of affection:

Affection is, from my perspective, the most meaningful approach to the relationship between ESD and phenomenon-based teaching. Our senses may be developed if we are affected by nature through being in it. Observing alpine plants affects me, because these small plants are so powerful. ESD presupposes that we are caring for the things we want to protect.

In order to link phenomenon-based teaching to the school subjects, the student teachers were encouraged to use the reverse curriculum approach (Bergli \& Myren, 1999); they start out from the phenomenon and analyse the potential learning outcomes by engaging in the phenomenon or assignment. 
Inquiry learning was also strongly applied. Inquiry learning is related to methods that support the pupils in learning about scientific inquiry and in developing knowledge of science concepts and NOS through an inquiry process (Crawford, 2014), and it was to a large extent linked to complexity and socio-scientific issues (SSIs) (Kolstø, 2001). The student teachers were also encouraged to work with their own subjects in order to develop teaching examples using inquiry learning.

\section{Science's distinctiveness and methodological character}

The ESD category science's distinctiveness and methodological character was addressed through an emphasis on the process dimension and the development of the student teachers' understanding of NOS. Pupils' understanding of NOS is important for decision making in the pupils' lives, especially within topics linked to SSIs (Kolstø, 2001). NOS was emphasised through inquiry learning, but was also treated as a separate element. How to work sustainably within the scientific discipline was, on the other hand, scarcely covered.

\section{ESD competencies}

Within ESD competencies, the analyses had a dual focus: how the student teachers were aware of and developed their own ESD competencies - and how the student teachers learned to facilitate the development of ESD competencies among pupils. The latter was linked to the working methods applied in the teacher education program, for example through the focus on inquiry learning, which facilitated the development of specific ESD competencies: problem-solving and creativity in answering the issue raised; systems thinking and critical thinking in order to assess the results; and collaboration and communication since inquiry tasks are often given to groups of learners.

Sociocultural learning theory emphasises the importance of a social community and collaboration as a part of teaching, learning and knowledge-building. The teacher education program contained much group work and the student teachers were also introduced to and experienced some distinct tools for learning collaboration. Through a pedagogical development project, the student teachers did not only experience collaboration, but also action. The ability to change a system is important in ESD, and through this project, where the student teachers had to actually do something, they may develop action competence. Action competence is 'the capacity to be able to act, now and in the future, and to be responsible for one's actions' (Jensen \& Schnack, 1997, p. 175), and according to Mogensen and Schnack (2010), an educational ideal in line with ESD.

In the final science education module, a major part of the module was devoted to a discussion on the different ESD competencies; the student teachers discussed why the competencies were important to develop in order to contribute to sustainable development and how the competencies had been addressed throughout the teacher education program.

\section{Lived ESD}

Whereas the other categories have the knowledge, skills and competencies of the pupils in mind, Lived ESD is more focused on how the teacher facilitates for the pupils' experience of ESD. The sociocultural perspective on learning creates a solid platform for the development of the social aspect of ESD. Empathy, attitudes and values (i.e. normative competence (Wiek et al., 2011)) form an implicit foundation for this teacher education institution, which strongly acknowledges social sustainability, and aims to have a university culture that mirrors the culture of a sustainable school. The learning environment was therefore the focus from day one of the program.

Founded in sociocultural learning theory, the significance of a social community and the feeling of safety and well-being as an integrated part of the learning process were acknowledged. Further, a mentor arrangement was another initiative that was organised to develop a safe learning environment; the teacher educators acted as mentors for groups of student teachers and guided them throughout the 
study. This was coupled to a specific focus on peer guidance where the student teachers supervised each other on the written assignments and acted as each other's writing buddies. Peer guidance was also practised and emphasised in smaller assignments and group work and some student teachers had their practical training in pairs. In order to give extra support to student teachers from other countries who struggled with the language, these student teachers were designated specific writing buddies who also corrected linguistic errors.

When it comes to the sub-category community engagement, the key emphasis placed on ESD was important in itself in order to create engagement. Moreover, the emphasis on science in context linked the teaching to societal issues, which may also create an awareness and engagement in the community. Another aspect is related to phenomenon-based teaching and how it may create affection, as described earlier. Finally, in order to gain a more global perspective, the students were encouraged to undertake some of their practical training in a developing country.

As a part of lived ESD, pupil participation can be linked to the student democracy and the methods for teaching and learning where the pupils need to be engaged in their learning process (e.g. phenomenon-based teaching and inquiry learning). Dewey (1938) considered experiential learning as a democratic learning process, as the working methods required active learners who shared their experiences. This is also a part of self-regulated learning, which was enhanced through the emphasis on student logs.

Finally, when it comes to sustainable school management/development, the emphasis both on peer guidance and on the pedagogical development project have potential when it comes to school development. There was also a theoretical introduction to organisational development in the teacher education program, and action research and action learning were presented as suitable working methods for school development. The student teachers were also encouraged to use action research to monitor and develop their teaching, involving a dynamic process of planning, observing, evaluating and re-planning (Gjøtterud \& Krogh, 2012).

\section{How do the student teachers in the teacher education program demonstrate understan- dings of ESD?}

An external evaluation of the teacher education programs (Dolin, Linløkken, Tonheim, \& Bildeng, 2012) concluded that although ESD was evident in the teacher education programs, the student teachers did not perceive ESD to be holistically realised. Analyses of student evaluation schemes showed the same tendency, but they also showed that there were differences in the student teachers' views regarding the realisation of ESD in the teacher education program. Some student teachers tended to see the sustainability perspective in all teaching modules as well as in the general learning environment, while other student teachers claimed that ESD was not included in the teacher education program at all. In the following, we will present the results of the analyses of the individual student assignments with respect to how the student teachers demonstrated their understanding of ESD.

Figure 2 shows the percentage distribution of the sub-categories among the science education assignments. The diagram illustrates that most student teachers in the analysis were focused on science in context (81\%). Several student teachers also discussed topics that were related to pupil participation (62\%) and collaboration (38\%). 


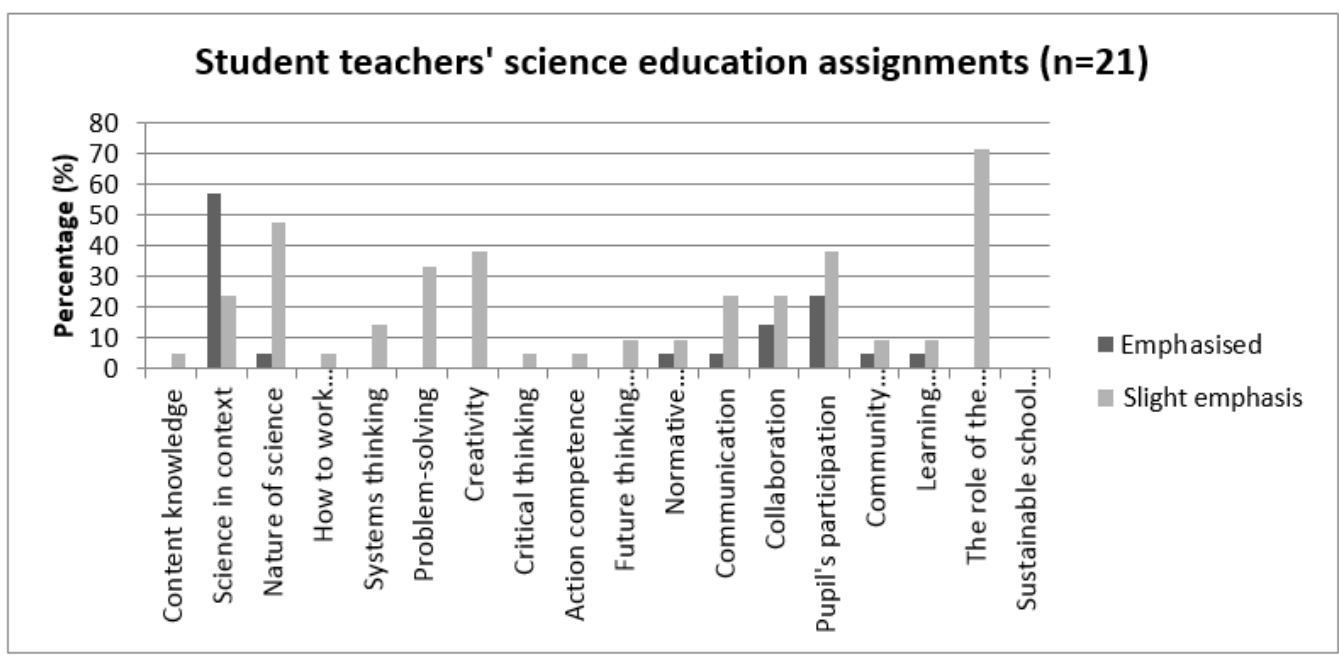

Figure 2. Percentage of science education assignments including sub-categories of ESD

Figure 3 shows the results of the analysis of the exam preparative assignments, where the student teachers reflected on how they had developed as teachers throughout the study. The student teachers focused on science in context (83\%), pupil participation (50\%) and collaboration (94\%) in this assignment as well, but they also emphasised other sub-categories such as normative competence (45\%), communication (56\%), community engagement (56\%) and the learning environment (83\%). All student teachers also wrote about the role of the teacher, but that was expected due to the task.

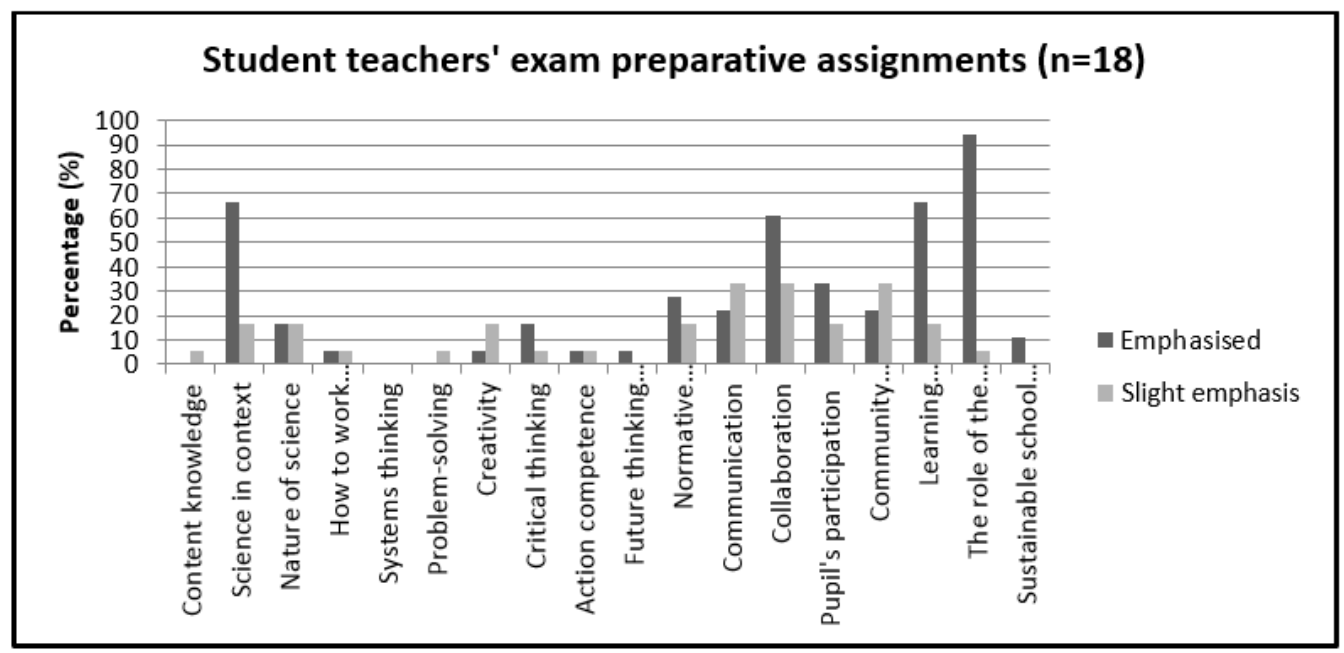

Figure 3. Percentage of exam preparative assignments including sub-categories of ESD

In the assignments, some student teachers demonstrated an explicit understanding of ESD, such as Erik, who had a background in ecology and nature conservation and followed the combined teacher education program in science and agriculture. He wrote about how he entered the teacher education program with a depth of knowledge about sustainable development, but that his experiences in the teacher education program changed his perception of ESD: 
My year in the teacher education program has taught me that ESD is much more than imparting knowledge about ecology. In retrospect, I would say that I have moved from looking at the school and my task as a teacher from teaching about sustainability, towards looking at my task as teaching for sustainability. I used to think about what the pupils needed to know about ecology and environmental management in order to understand sustainability, but I am now thinking more about how I can help the pupils to become independent, critical and creative problem solvers driven by their own engagement and empathy. (Exam preparative assignment, Erik)

Another student teacher who was explicit in terms of her perspective on ESD was Marianne who discussed the role of peer guidance in sustainable development of the school and school system:

Peer guidance is an important tool because the teachers may develop a common understanding of how one should work in the school and why. It is required that teachers are open to suggestions, discussion and guidance from other colleges in order to encourage their own development and school development. I believe this is important in order to promote sustainable development of the school system. In this way, the school itself may become a learning organisation in which the pupils, teachers and management continuously evolve and learn. (Exam preparative assignment, Marianne)

Marianne also linked inquiry learning and ESD and was thereby explicit about the role of inquiry learning for ESD by pointing to how inquiry learning may facilitate creative and critical thinking and understanding for scientific working methods.

The excerpts taken from the assignments of Erik and Marianne were more particular than ordinary. Most other student teachers were less explicit with respect to their understanding of ESD. The focus on NOS and the ESD competencies of problem-solving, creativity and critical thinking in the assignments was mainly due to an emphasis on inquiry learning, as was drawn attention to by Marianne. In addition, when discussing science in context, several student teachers wrote about phenomenonbased teaching, such as in this excerpt by Mette, who showed an appreciation of phenomenon-based teaching as a tool with which to understand science in an everyday context:

After being introduced to the topic of phenomenon-based teaching in this study, I have finally been able to identify something that was lacking from my studies: being able to connect the sciences to an everyday context. It was only at a later stage that I managed to move from abstract matter into the concrete, thus being able to see things from a broader perspective. (Science education assignment, Mette)

\section{Discussion}

The purpose of this study was to investigate how a teacher education institution with an overall aim of educating teachers who can contribute to sustainable development includes such practices in the education of science teachers. In this section, the findings from the case study will be used to discuss how ESD can be realised in science teacher education. We will begin with a focus on the student teachers and what they need to learn and experience in order to realise ESD. We will thereafter discuss the ESD realisation in the teacher education program under study and how the realisation can be improved.

Scott (1996) emphasised that teacher education programs should educate teachers who are both willing and able to contribute within ESD. In order to be able to realise ESD, a broad understanding of the concept is necessary (Hopkins \& McKeown, 2002). We have earlier pointed to science teachers tending to be oriented towards the fact-based teaching tradition (Borg et al., 2012). In the excerpt 
from the student teacher Erik, he wrote that his understanding of ESD had changed throughout the study, moving from teaching about sustainability to teaching for sustainability. Hence, he moved from a fact-based to a pluralistic teaching tradition. The aim of the pluralistic tradition is to 'enhance the students' democratic action competence' (Rudsberg \& Öhman, 2010, p. 97). It, hence, involves to become competent in acting consciously and participating reflectively in the sustainability debate (Öhman, 2007). This is in line with Erik's focus on helping learners become 'independent, critical and creative problem solvers driven by their own engagement and empathy'.

Scott (1996) also emphasised the need for a repertoire of suitable pedagogical approaches in order to be able to realise ESD. The model for planning and analysing ESD is one tool that can guide the realisation of ESD, and the model is designed in a way that allows the teachers to introduce ESD gradually (Jegstad \& Sinnes, 2015). The teacher education program being studied founded the realisation of ESD in existing practices; the approach to ESD did therefore follow a strengths model (Hopkins \& McKeown, 2002). From the analysis, we can see that the choice of working methods facilitated the development of specific categories of the model, in line with education through science (Holbrook, 2005). Thus, realising ESD is about finding teaching and working methods that facilitates for the development of ESD competencies and the other categories of the ESD model. We have already given specific examples in the result section, and some will be lifted up in this section as well.

Within lived ESD, the student teacher Marianne pointed to the role of peer guidance and how 'the school itself may become a learning organisation in which the pupils, teachers and management continuously evolve and learn'. She thereby pointed to how the teacher education program can facilitate sustainable school management and development. Further, through the university culture, the student teachers experienced a safe and friendly learning environment, where collaboration was important and where diversity, both among student teachers and teacher educators was valued (Sterling, 2009). Thus, through exemplary teaching experiences, such as peer guidance, the residential field course and the mentor arrangement, the student teachers experienced good relations and a good learning environment themselves, and the aim is that they will include similar practices in their future professions.

Phenomenon-based teaching and inquiry learning were other approaches taken towards ESD. According to the student teacher Mette, phenomenon-based teaching helped her 'move from abstract matter into the concrete, thus being able to see things from a broader perspective'. This higher understanding and ability to see the broader picture is important within ESD, especially connected to the three perspectives of ESD, as ESD is often explained by a model emphasising the economic, social and environmental aspects (McKeown \& Hopkins, 2003). Hence, when addressing scientific issues, they should be linked to the economic and social aspects as well. This requires seeing things from a broader perspective and is linked to the ESD competence systems thinking.

Within inquiry learning, the student teacher Marianne pointed to how inquiry learning facilitated pupil participation, introduction to scientific working methods and ESD competencies such as creativity and critical thinking. Since inquiry learning in this teacher education program was linked to complexity and SSIs, the importance of these competencies was increased.

The analyses showed that the focus in the student teachers' assignments was in accordance with the focus in the teacher education program, indicating that the teaching affected the science educational engagement of the student teachers. Especially the categories science in context, collaboration and pupil participation were emphasised. Societal relevance and pupil participation were key-issues throughout the year through the focus on phenomenon-based teaching, inquiry learning and other pupil active teaching methods and these were also topics many student teachers addressed in their assignments. Further, the student teachers had to collaborate in most sessions in the teacher education program - and many student teachers followed up with a focus on collaboration in their assignments. 
Even though the foci of the assignments were in accordance with the ESD realisation in the teacher education program, there were some discrepancies in how the student teachers understood the ESD realisation. One explanation of this discrepancy is linked to how explicit the teacher educators were with respect to ESD in the teacher education program. To illustrate this by an example, Marianne's emphasis on sustainable school development and management was founded on her own interpretation. An important question is therefore linked to how we can ensure that the focus on ESD is made explicit to all student teachers. A characteristic found in the analysis of the teacher education program was that the ESD expression was somewhat implicitly covered and therefore not understood by all students.

In the teacher education program being studied, exemplary teaching is used. According to the local curriculum, the teaching should be experienced and discussed as a part of the program content (NMBU, 2009). Student teachers enter the teacher education program with preconceptions about teaching and learning; the inclusion of sufficient suitable experiences and opportunities for the student teachers to reflect on these experiences is therefore emphasised (Korthagen \& Lagerwerf, 2001). This is in line with exemplary teaching, but it might appear as if parts of the meta-perspective were lacking from this teacher education program. It could therefore be suggested that more meta-reflection be included with respect to the ESD terminology and how ESD is realised. This is especially important in science education programs, since student teachers within a fact-based teaching tradition may need more explicit guidance in order to reveal the ESD expression and contribute with a teaching tradition more in line with ESD.

More meta reflection would also be necessary with respect to the realisation of the specific subcategories. One suggestion could be to move the reflection on the ESD competencies forward in order to initiate an earlier awareness of the topic. This reflection could also include other elements of ESD and perhaps guide the student teachers in further development of their teacher competency throughout the program.

Another way to achieve the exemplary to be explicit enough, could be if the teaching staffs analysed their own teaching sessions in order to be conscious about the ESD aspect of their own teaching. The ESD expression has to be clear for the teacher educators in order to be clear for the student teachers. This would be especially important in a teacher education program where the strengths model has been applied in the development of the ESD expression, since the teacher educators build on something they have done earlier, before ESD was chosen as an overall aim. Such an analysis could also contribute to development of the ESD expression in the teacher education program, where the teaching staffs themselves are able to identify the potential and the strengths and weaknesses with their own teaching and thereby develop the realisation of ESD further.

\section{CONCLUDING REMARKS}

In this paper, we have given an example of how a teacher education institution in Norway realised ESD through a strengths model by building on elements already present in the teacher education program, such as phenomenon-based teaching and inquiry learning. In case study research, a single case is preferred when the case represents a unique or rare case (Yin, 2009), such as in this study due to the overall aim of the teacher education program. Corcoran et al. (2004) stressed that every school or institution is different, and one should therefore not look for universal ESD models, but rather consider how the practice in one institution can be transformative for another institution. Consequently, they emphasised the importance of thorough documentation for the study to have transformative value for others. This is in line with reader-based analytical generalisation, introduced by Kvale and Brinkmann (2009), where the reader judges whether the findings may be generalised. 
From the study, we can see that the emphasis on sociocultural learning theories contributed to social sustainability in terms of both the atmosphere of and the working methods employed in the teacher education program, and that the experiential learning and pupil-centred teaching approaches - such as phenomenon-based teaching and inquiry learning - built a thorough foundation for ESD competencies and other aspects of the ESD model. However, we also found that the ESD realisation needs to be explicit. Student teachers such as Marianne and Erik showed a well-developed understanding of ESD in their assignments, but many student teachers need more guidance and explicit teaching. They also need guidance about the concept of ESD. The expression of ESD was developed within the teacher education institution and is continuously in development through ongoing research and development projects, and these are factors to be kept in mind.

\section{REFERENCES}

Bergli, T., \& Myren, K. A. (1999). Sammenheng mellom opplæring i skole og bedrift (Correlation between training in schools and companies). In T. Bergli (Ed.), Inlärning i skola och företag: Nordisk yrkespedagogisk FoU-program.

Borg, C., Gericke, N., Höglund, H.-O., \& Bergman, E. (2012). The barriers encountered by teachers implementing education for sustainable development: Discipline bound differences and teaching traditions. Research in Science \& Technological Education, 3o(2), $185-207$.

Burmeister, M., \& Eilks, I. (2013). An understanding of sustainability and education for sustainable development among German student teachers and trainee teachers of chemistry. Science Education International, 24(2), 167-194.

Burmeister, M., Rauch, F., \& Eilks, I. (2012). Education for sustainable development (ESD) and chemistry education. Chemistry Education Research and Practice, 13, 59-68.

Corcoran, P. B., Walker, K. E., \& Wals, A. E. (2004). Case studies, make-your-case studies, and case stories: a critique of case-study methodology in sustainability in higher education. Environmental Education Research, 10(1), 7-21.

Corney, G., \& Reid, A. (2007). Student teachers' learning about subject matter and pedagogy in education for sustainable development. Environmental Education Research, 13(1), 33-54.

Crawford, B. A. (2014). From inquiry to scientific practices in the science classroom. In N. G. Lederman \& S. K. Abell (Eds.), Handbook of research on science education (Vol. 2, pp. 515-544). New York: Routledge.

Dahlin, B., Östergaard, E., \& Hugo, A. (2009). An argument for reversing the bases of science education: a phenomenological alternative to cognitionism. Nordic Studies in Science Education, 5(2), 185-199.

de Haan, G. (2010). The development of ESD-related competencies in supportive institutional frameworks. International Review of Education, 56(2-3), 315-328.

Dewey, J. (1938). Experience and Education. New York: Kappa Delta Pi/Touchstone.

Dillon, J. (2012). Science, the Environment and Education Beyond the Classroom. In B. J. Fraser, K. Tobin, \& C. J. McRobbie (Eds.), Second International Handbook of Science Education (pp. 1081-1095). New York: Springer.

Dolin, J., Linløkken, A., Tonheim, E., \& Bildeng, C. N. (2012). Evaluation af Praktisk pedagogisk utdanning (PPU) og Lektorutdanning i realfag (LUR) ved Universitetet for miljø- og biovitenskap (UMB) (Evaluation of the teacher education programs at NMBU). Retrieved from http:// www.nmbu.no/sites/default/files/pdfattachments/umb_rapport_final_3ojuni_2012.pdf

Flick, U. (2004). Triangulation in qualitative research. In U. Flick, E. von Kardorff, \& I. Steinke (Eds.), A companion to qualitative research (pp. 178-183). London: SAGE Publications Ltd.

Gjøtterud, S. M. (2011). Utvikling av veiledningsmøter i praktisk-pedagogisk utdanning - Aksjonsforskning i lærerutdanneres praksis (Developing guiding encounters in practical and didactical education - Action research in teacher educators' practice). (Doctoral dissertation), Universitetet for miljø- og biovitenskap, Ås. 
Gjøtterud, S. M., \& Krogh, E. (2012). Action research as an approach to professional and organizational development in teacher education. Action Research, 3(3), 66-83.

Holbrook, J. (2005). Making chemistry teaching relevant. Chemical Education International, 6(1), 1-12.

Hopkins, C., \& McKeown, R. (2002). Education for sustainable development: an international perspective. In D. Tilbury, R. B. Stevenson, J. Fien, \& D. Schreuder (Eds.), Education and Sustainability: Responding to the Global Challenge. Gland, Switzerland and Cambridge, UK: Commission on Education and Communication, IUCN.

Jegstad, K. M., \& Sinnes, A. T. (2015). Chemistry teaching for the future: A theoretical model for upper secondary chemistry education for sustainable development. International Journal of Science Education, 37(3-4), 655-683.

Jensen, B. B., \& Schnack, K. (1997). The action competence approach in environmental education. Environmental Education Research, 3(2), 163-178.

Karpudewan, M., Hj Ismail, Z., \& Mohamed, N. (2011). Greening a chemistry teaching methods course at the School of Educational Studies, Universiti Sains Malaysia. Journal of Education for Sustainable Development, 5(2), 197-214.

Kirk, J., \& Miller, M. L. (1986). Reliability and validity in qualitative research. Beverly Hills: Sage Publications.

Kolstø, S. D. (2001). Scientific literacy for citizenship: Tools for dealing with the science dimension of controversial socioscientific issues. Science Education, 85(3), 291-310.

Korthagen, F. A. J., \& Lagerwerf, B. (2001). Teachers' Professional Learning: How Does It Work? In F. A. Korthagen, J. Kessels, B. Koster, B. Lagerwerf, \& T. Wubbels (Eds.), Linking practice and theory: The pedagogy of realistic teacher education (pp. 175-206). New Jersey: Routledge.

Kvale, S. (1996). Interviews: an introduction to qualitative research interviewing. Thousand Oaks, California: Sage Publication, Inc.

Kvale, S., \& Brinkmann, S. (2009). Interviews: learning the craft of qualitative research interviewing (2nd ed.). Thousand Oaks: SAGE Publications, Inc.

Lave, J., \& Wenger, E. (1991). Situated learning. Legitimate peripheral participation. New York: Cambridge University Press.

Lederman, N. G., \& Lederman, J. S. (2012). Nature of scientific knowledge and scientific inquiry: Building instructional capacity through professional development. In B. J. Fraser, K. Tobin, \& C. J. McRobbie (Eds.), Second International Handbook of Science Education (pp. 335-359). New York: Springer.

McKeown, R., \& Hopkins, C. (2003). EE $\neq$ ESD: Diffusing the Worry. Environmental Education Research, 9(1), 117-128.

Mogensen, F., \& Schnack, K. (2010). The action competence approach and the 'new' discourses of education for sustainable development, competence and quality criteria. Environmental Education Research, 16(1), 59-74.

NMBU. (2009). Fagplan PPU (Local curriuculum for the teacher education program).

Rauch, F., \& Steiner, R. (2013). Competences for Education for Sustainable Development in Teacher Education. Centre for Educational Policy Studies Journal, 3, 9-24.

Rudsberg, K., \& Öhman, J. (2010). Pluralism in practice-experiences from Swedish evaluation, school development and research. Environmental Education Research, 16(1), 95-111.

Scott, W. (1996). The environmentally educating teacher: synthesis of an implementation theory for pre-service courses. Australian Journal of Environmental Education, 12, 53-60.

Sinnes, A. T., \& Jegstad, K. M. (2011). Utdanning for bærekraftig utvikling: to unge realfagslæreres møte med skolehverdagen (Education for sustainable development: two young science teachers' encounter with school life). Norsk Pedagogisk Tidsskrift, 95(4), 248-259.

Sterling, S. (2009). Sustainable Education: Re-visioning Learning and Change. Dartington: Green Books Ltd. 
Summers, M., Childs, A., \& Corney, G. (2005). Education for sustainable development in initial teacher training: issues for interdisciplinary collaboration. Environmental Education Research, 11(5), 623-647.

UNESCO. (2005). United Nations Decade of Education for Sustainable Development (2005-2014): International Implementation Scheme. Retrieved from

UNESCO. (2016). Global Action Programme on ESD. Retrieved from http://en.unesco.org/gap

Voogt, J., \& Roblin, N. P. (2012). A comparative analysis of international frameworks for 21st century competences: Implications for national curriculum policies. Journal of Curriculum Studies, 44(3), 299-321.

Vygotsky, L. S. (1978). The Development of Higher Psychological Processes. Cambridge, MA: Harvard University Press.

Wals, A. E. (2011). Learning our way to sustainability. Journal of Education for Sustainable Development, 5(2), 177-186.

Ware, S. A. (2001). Teaching chemistry from a societal perspective. Pure and Applied Chemistry, 73(7), 1209-1214.

Wiek, A., Withycombe, L., \& Redman, C. L. (2011). Key competencies in sustainability: a reference framework for academic program development. Sustainability Science, 1-16.

Yin, R. K. (2009). Case study research: Design and methods. Los Angeles: Sage.

Öhman, J. (2007). The ethical dimension of ESD - navigating between the pitfalls of indoctrination and relativism. In I. Björneloo \& E. Nyberg (Eds.), Drivers and barriers for implementing learning for sustainable develoment in pre-school through upper secondary and teacher education (pp. 43-47). Göteborg: UNESCO. 